\title{
Feminističke kustoske prakse: od pojedinačnoga angažmana do ženskog muzeja
}

Bratić, Martina

Source / Izvornik: Institucije povijesti umjetnosti : zbornik 4. kongresa hrvatskih povjesničara umjetnosti, 2019, 91 - 95

Conference paper / Rad u zborniku

Publication status / Verzija rada: Published version / Objavljena verzija rada (izdavačev PDF)

https://doi.org/10.31664/z4khpu.11

Permanent link / Trajna poveznica: https://urn.nsk.hr/urn:nbn:hr:254:971523

Rights / Prava: Attribution 4.0 International/Imenovanje 4.0 međunarodna

Download date / Datum preuzimanja: 2023-04-26

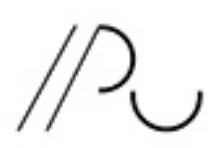

INSIIIUTR ZA POVIJESTUMJETNOSI
Repository / Repozitorij:

PODEST - Institute of Art History Repository

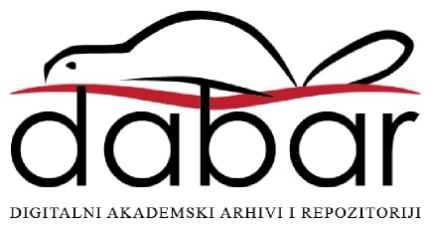




\section{Feminističke kustoske prakse: od pojedinačnoga angažmana do ženskog muzeja}

Govoreći o impulsima suvremenih muzejskih dispozicija, odnosno, promatrajući programska nagnuća velikih muzejskih institucija diljem Europe ili Sjeverne Amerike, ideja o feminističkim teorijama i metodologijama kao nedjeljivima od današnje muzejske produkcije pronalazi sebi sve više prostora u recentnim stručnim napisima i raspravama. ${ }^{1}$ Razvoj feminističke umjetnosti (i umjetničkih tendencija na ovaj ili onaj način dotaknutih feminističkom mišlju), kao logičnu aktualizaciju doživio je i rastući interes javnih muzejskih institucija za priključenje feminističkih i rodnih perspektiva u okvire vlastitih koncepcija.

Sustavnije početke i stasanje feminističke umjetničke djelatnosti moguće je pratiti usporedno s jasnije provođenim i implementiranim feminističkim idejama u okviru političko-društvene zbilje, s okvirnim vremenskim određenjem u ranim sedamdesetim godinama prošloga stoljeća. Njezina vidljivost, a kao njezin uvjet prisutnost u kanalima umjetničke produkcije, pokazala se primarnim zadatkom u prezentaciji tih angažiranih oblika suvremene umjetničke produkcije. Samostalni napori pojedinačnih umjetnica ili pak njihova manje ili više formalna udruženja kroje povijesni nacrt feminističkih kustoskih praksi u začecima. Pristup tomu nacrtu, doduše, moguć je gotovo isključivo kartografskim tretmanom, a nipošto pokušajem uspostavljanja ikakve linearno-kauzalne logike.

Tadašnja udruženja žena umjetnica, osim same umjetničke proizvodnje, pretpostavljala su i poziciju onoga što (danas) poimamo pod terminom kustos, posvetivši se predstavljanju isključivo ženske umjetnosti i/ili umjetnosti koju su stvarale žene. Pa ipak, danas, gotovo pola stoljeća poslije, rasprave o već uspostavljenim modelima ili o onima koje bi tek mogla stvoriti feministička umjetnička produkcija i, još važnije, o njezinim interpretacijskim i prezentacijskim potencijalima, doimaju se sve glasnije i sve više prisutne. „Ukoliko [...] podrazumijevamo izložbe kao mjesto diskursa, apsolutno je nužno tražiti i dublje

\section{Martina Bratić}

Institut za muzikologiju Sveučilište Karl-Franzens u Grazu martina.bratic@uni-graz.at

https://orcid.org/oooo-oooI-9034-8905
I JESSiCA SJÖHOLM SKRUBBE, Preface, u: Curating Differently: Feminisms, Exhibitions and Curatorial Spaces, (ur.) Jessica Sjöholm Skrubbe, Newcastle upon Tyne, 20I6., XI-XVIII, XI. 
razumijevanje feminističkih izložbi i kustoskih praksi u relaciji prema širim političkim, ekonomskim i socijalnim strukturama u lokalnim ali i globalnim kontekstima. Pa ipak je, i tomu unatoč, teorijsko promišljanje koje u svojemu središtu ima kuriranje feminističke umjetnosti, kao i povijest feminističkih izložbi, kao specifično područje znanja svoje konture zadobilo tek nedavno."

Upravo zahvaljujući takvoj recentnoj proliferaciji rasprava i zaključaka o feminističkoj kustoskoj praksi kao zasebnome području djelovanja, ali i broju i učestalosti izložbi, konferencija, istraživačkih mreža, simpozija i brojnih različitih publikacija, Elke Krasny vjeruje da je moguće govoriti i o svojevrsnome feminističkom obratu u okviru međunarodnih kustoskih praksi. ${ }^{3}$ Ona je ujedno i jedna od najčešće spominjanih teoretičarki koje se bave upravo pitanjem feminističke misli u okviru kustoskih praksi i njezinih potencijala i dosega. Što je feministički obrat u kuriranju; što on čini i kakve posljedice ima za historijski nacrt kustoskih praksi ili, s druge strane, kakvu poziciju zauzima u procesima kustoske produkcije znanja samo su neka od pitanja koja je Elke Krasny otvorila u jednome od dva svoja recentna doprinosa nezavisnome stručnom web-časopisu posvećenu kustoskim praksama i teoriji On Curating. ${ }^{4}$ A upravo se raspravom o metodi feminističkih čitanja i koncepcija uokvirio jedan od spomenutih tekstova, u kojemu je autorica, u nastojanju definiranja feminističke misli, njezinu metodu označila kao-pitanje. „Pitanje kao metoda" jedino je moguće usmjerenje feminističkoga čitanja, jer ono, ali i feministička metoda- „opiru se definiciji i odbijaju svesti na jednu monolitnu i definitivnu definiciju", reći će Elke Krasny. ${ }^{5}$ Pa ipak, usprkos nemogućnosti vezivanja ili sputavanja definicijom, feministička misao u okvirima umjetnosti doživjela je besprimjernu kritičku pozornost unatrag deset do petnaest godina, kako upozorava uredništvo broja On Curating posvećena upravo temi feminističkoga kuriranja. ${ }^{6}$

Od izložbi koje su u istoj raspravi postale paradigmatskim primjerima feminističke umjetnosti i kustoskih koncepcija su, primjerice, američke izložbe WACK! i Global Feminisms iz 2007., zatim The Furious Gaze, predstavljena u španjolskome Montehermosu, a o istočnoeuropskoj perspektivi progovorila je izložba ali i sveobuhvatan istraživački projekt Bojane Pejić i njezina tima suradnika-Gender Check iz 2009. Iste je godine Camille Morineau u pariškome Centre Pompidou postavila i elles@centrepompidou, s djelima iz stalne kolekcije, izloživši djela isključivo autorica. Jedan je od posljednjih doprinosa i izložba posljednjega projekta feminističke aktivističko-umjetničke grupacije Guerilla Girls, nazvana Is It Even Worse in Europe?, otvorena u listopadu 2or6. u londonskoj galeriji Whitechapel, a bavila se kritičkim rastakanjem narativa i kanona koje kreiraju kulturne institucije.

Gotovo se usporedno može pratiti i pojačana produkcija napisa i brojnih publikacija koje su u žarište stavile tu temu, a neke su od najrecentnijih-Issues in Feminist Curation: Strategies and Practices iz 2006., autorice Katy Deepwell, zatim publikacija Feminisms is Still Our Name: Seven Essays on Historiography and
2 JESSICA SJÖHOLM SKRUBBE (bilj. I), XII. Svi su prijevodi autoričini.

3 ELKE KRASNY, Introduction, u: Women's:Museum: Curatorial Politics in Feminism, Education, History, and Art, (ur.) Elke Krasny, Beč, 20I3., Io-29, 25.

4 Riječ je o člancima: ELKE KRASNY, Feminist Thought and Curating: On Method, u: On Curating, 26 (20I5.), 5I-69 i ISTA, Curatorial Materialism: A Feminist Perspective on Independent and Co-Dependent Curating, u: On Curating, 29 (20I6.), 96-ıo6.

5 „Promotrimo li ga kroz prizmu pitanja kao metode, feminizam ostaje baziran na paradoksu da nikada ne nudi odgovor, dok istovremeno, ne prestaje uvijek i iznova propitivati," dodaje još Krasny. ELKE KRASNY (bilj. 4, 2OI5.), 52, 57 .

6 ELKE KRASNY, LARA PERRY, DOROTHEE RICHTER, Curating in Feminist Thought, u: On Curating, 29 (20I6.), 2-4, 2. 
Curatorial Practices, urednicâ M. H. Hayden i J. S. Skrubbe iz 20I0.; Politics in a Glass Case: Feminism, Exhibition Cultures and Curatorial Transgressions (ur. A. Dimitrakaki i L. Perry, 20I3.); Women's:Museum. Curatorial Politics in Feminism, Education, History, and Art (20I3.), urednice Elke Krasny ili najnovija u nizu, zbornik Curating Differently: Feminisms, Exhibitions and Curatorial Spaces, izdan 2016. godine.

Stručni skupovi također prate stanovitu razvojnu liniju u pristupu temi, otpočevši s pitanjima feminističke misli u umjetnosti samoj, do sasvim recentnih, koji promišljaju širu sliku kuriranja feminističke umjetnosti, ali i mogućnosti uspostave zasebnoga polja feminističkoga kuriranja. Izdvojit ću skupove Dialogues and Debates (Feminist Positions in Contemporary Visual Arts) (Nürnberg, I999.); Women's:Museum: Between Collection Strategies and Social Platforms (Beč, 2ого.); Curating Feminism (Sydney, 20I4.) te Curating in Feminist Thought, održan u svibnju 2oI6. u Zürichu.

U ovakvim pokušajima historizacije feminističke umjetnosti i načina njezine prezentacije važno je upozoriti i na sve snažniju prisutnost rasprava o kustoskim praksama kao nezavisnome području istraživanja. Kasne šezdesete i početak sedamdesetih godina prošloga stoljeća stvorili su mjesto kustosu kao stvaraocu, kako to naglašava Bruce Altshuler, što je punokrvni boom doživjelo dva desetljeća poslije. ${ }^{7}$ Devedesete su, naime, predstavile kustosku poziciju kao gotovo al pari onoj umjetničkoj, sada dodatno pojačanu brojnim moćnim umjetničko-produkcijskim institucijama i njihovim međusobnim vezama, što je pak u danome trenutku otvorilo put i nekoj vrsti kulturne hegemonije, posegnemo li za pojmom Antonija Gramscija. ${ }^{8}$

Ipak, ono kroza što su kustoske prakse, kao novouspostavljeno polje umjetničkoga i teorijskog djelovanja, neminovno morale proći, bio je izostanak metodološkoga okvira, nedostatak teorijskoga promišljanja i diskursa, kao i fragmentiran i nikada čvrsto usidren plan vlastite historiografije. Za svoj je rezultat takva situacija imala upravo nastojanje kustosa samih da preispitaju vlastite ideje i pokušaju re-kreirati svoje izlazne točke u procesima produkcije znanja. Stoga je i stanovito bujanje u području istraživanja upravo kustoskih praksi kao institucionalnoga, odnosno trans-institucionalnoga mjesta u okviru discipline u posljednjemu desetljeću istaknulo to pitanje kao snažno prisutno i relevantno, uspostavljajući jedan novi diskurs i potencijalne ulazne točke $u$ jedno drukčije čitanje (i posljedično-stvaranje) povijesti umjetnosti. Jer je upravo „kroz 2o. stoljeće, reći će Boris Groys, izložbena povijest nedjeljiva od povijesti umjetnosti te izložba postaje medijem u kojemu je većina umjetnosti vidljiva-ona, dakle, administrira kulturno značenje umjetnosti". ${ }^{9}$

Osim individualnih publikacija, primjetan je i porast broja znanstvenih časopisa posvećenih kustoskim teorijama i praksama, kao što su Curator: The Museum Journal (I985.-), Manifesta Journal: Around Curatorial Practice, pokrenut 2003. godine, zatim On Curating (2008.) ili Journal of Curatorial Studies (2012.-). Također, od 20ıo. istraživački je centar londonskoga University of the Arts-Afterall-započeo s izdavanjem Exhibition
7 IVANA MEŠTROV, MIHAELA RICHTER, Fragmenti kustoskog diskursa, u: Život umjetnosti, 85 (2009.), $4^{-\mathrm{I}} 3,6$.

8 U pokušaju skiciranja trajektorije rasprava o kustoskoj perspektivi kao autorskoj, ovdje ću izdvojiti tek neke od publikacija: NATHALIE HEINRICH, MICHAEL POLLAK, From Museum Curator to Exhibition Auteur: Inventing a Singular Position, u: Thinking about Exhibitions, (ur.) Reesa Greenberg, Bruce W. Ferguson, Sandy Nairne, London, I996; KARSTEN SCHUBERT, The Curator's Egg: The Evolution of the Museum Concept from the French Revolution to the Present Day, London, 200o., ili, primjerice, HANS ULRICH OBRIST, A Brief History of Curating, Zürich, Dijon, 2008.; ISTI, Everything You Always Wanted to Know About Curating But Were Afraid to Ask, 20II. i ISTI, Ways of Curating, 20I4.

9 IVANA MEŠTROV, MIHAELA RICHTER (bilj. 7), 9. 
Histories Series, serije publikacija koja nastoji rekonstruirati povijest umjetnosti kroz historiografiju velikih izložbi, a upravo u vrijeme uspostave pozicije nezavisnoga kustosa.

I upravo su gore opisana individualizacija profesije, kao i nužnost stvaranja metodološke aparature prema modelu autoreferencijalnosti i introspekcije, jedne od ključnih poveznica između feminističkih umjetničkih praksi i kuriranja, na što je sasvim precizno ukazala i Elke Krasny, označivši feminističku misao kao onaj alat kojim čita, „analizira, historizira, teoretizira i prakticira to polje". Pritom će upozoriti i da je taj alat u srži problematičan jer se ne da fiksirati: „feministička misao izražava izraziti otpor biti vezana definicijom, feministička misao traži definiciju; feministička misao traži stalnu redefiniciju u odnosu na definiciju". Pokušaj lociranja feminističke misli u već postojećim povijesnim uvjetima, odnosno, kako sama kaže-paradigmatskim historiografijama, sa sobom uvijek nosi nužnost operiranja „protiv struje linearnih narativa razvitka”. Drugim riječima, u nastojanju implementiranja feminističke misli u bilo kakav povijesni (ili realno-sadašnji) kontekst, čini se nužnim izbjegavati strogo historijski usmjerena čitanja i prikloniti se sistematskoj analizi avremenskoga karaktera. „Kako bi se izbjegla zamka 'nekritičke kronologije', potrebno je okrenuti se "kritičkoj kartografiji". ${ }^{10} \mathrm{Na}$ sličan se način, stoga, može pristupiti i samu kustoskom projektu, čije povijanje definiciji, jednako tako, nije bez otpora. On, kao i feministička misao, u sebi objedinjuje i stanovit paradoks, a to je „želja da kustoske prakse budu shvaćene i poimane kao zasebno specifično područje znanja, ali i želja da se to isto područje ne ograničava definicijama koje sužavaju". Kustoske prakse, u današnjemu smislu otpočete paralelno s idejama feminizma kao političko-društvenoga, ali i kulturno-umjetničkog pokreta, $\mathrm{u}$ toj su svojoj fazi olabavile veze s dominantnim konceptima prikupljanja, konzerviranja, kategorizacije i prezentacije kao prapočela povijesnoumjetničke kontekstualizacije i analize. U opcrtavanju gore spomenutih relacija između feminizma i kustoskih praksi, odnosno njihove formativne faze, Elke Krasny ide čak korak dalje kada kaže: „Upravo se kroz feminističku kritiku u šezdesetima i sedamdesetima kuriranje suočilo sa svojom hegemonijskom i isključivačkom politikom, ali i doživjelo znatne promjene kasnije." ${ }^{\prime 1}$

Povijest feminizma pisana je (pa i čitana) kao ideja progresiune kronologije, kako to tumači Krasny. Odnosno, njezin historiografski model čine sukcesivni valovi; prvi, drugi, treći i, kako pojedina epistemološka čitanja predlažu-četvrti val (ili, s druge strane, možemo govoriti o terminima kao što su pred-feminizam, feminizam ili postfeminizam). Primijeni li se spomenuta paradigma na pitanje feminističke umjetnosti, njezina kuriranja i posljedicâ njihovih odnosa, fenomen ženskih muzeja nadaje se kao još jedna karika u lancu te iste progresije. Ideja inicirana osamdesetih, u jeku onoga što se naziva drugim valom feminizma, okupljala je gotovo beziznimno žensku inicijativu, odnosno ponovno onaj model individualnoga angažmana kao svoje začetničke iskre. Najraniji takav tip muzeja jest Frauenmuseum u Bonnu, osnovan I98I.,
IO ELKE KRASNY (bilj. 4, 2OI5.), 5I-52. II ELKE KRASNY (bilj. 4, 2OI5.), 53-54. 
a slijedili su ga danski primjer iz I982. te potom i Ženski muzej otvoren u talijanskome Meranu I988. godine. Danas je prisutno šezdesetak takvih muzeja, aktivnih između ostaloga u Italiji, Njemačkoj, Austriji, Ukrajini, Albaniji, Norveškoj, Španjolskoj, zatim u SAD-u, Kanadi, Meksiku, Argentini, itd.; njihovo je mapiranje rezultiralo i sve snažnijom i tješnjom konceptualnom i logističkom mrežom, na čijim se temeljima osnivaju i razne asocijacije, održavaju kongresi i druge aktivnosti.

Ono što, dakako, leži u srži njihova nastanka i postojanja jesu specifičan prezentacijski diskurs i regulacija (postojećih) historijskih, ekonomskih, društvenih i političkih pozicija koje žena može zauzimati (i performirati). U isto će vrijeme takav tip prezentacijskoga terena činiti i mjesto jedne drukčije, pa i alternativne umjetničke produkcije, dakle produkcije onkraj kanona, a koja bi posljedično kreirala i jednu drukčiju, alternativnu povijest umjetnosti.

Feministička je misao postala integralnim dijelom kustoskih inicijativa u 2I. stoljeću, u okviru čega su kustosi, istraživači i teoretičari to isto polje umnogome transformirali, posljednjih se godina sve aktivnije posvetivši produkciji teorijskoga diskursa i pokušajima historiografiranja feminističkoga kuriranja. Kustosko posredovanje ideja, koncepata i znanja jest također jedan od presudnih aspekata u načinu na koji se povijest umjetnosti piše i prenosi, a u tome smislu preostaje tek vidjeti kakvu će umjetnost za svoju posljedicu imati sukus feminističke (i queer) misli s kolaboracijskim kuriranjem.

$\mathrm{Na}$ kraju, važnost ove teme ogleda se i u njezinoj aktualnosti i recentnoj proliferaciji rasprava o njoj, jer dok su kustoske prakse kao profesija i polje djelovanja polako ali sigurno već uspostavile vlastiti historiografski tijek, pitanja feminističke kustoske prakse, a napose fenomena ženskih muzeja, tek trebaju stvoriti nacrt vlastitih estetskih, metodoloških, teorijskih, političkih i drugih agendi. Takav bi potom nacrt mogao činiti orijentacijski reper u kretanju ovim terenom, bilo kroz njegovu prošlost, sadašnjost ili pak budućnost.

\section{() (1)}

Feminističke kustoske prakse: od pojedinačnoga angažmana do ženskog muzeja/Martina Bratić/ CC BY / 4.0

DoI: https://doi.org/Io.3I664/z4khpu.II 